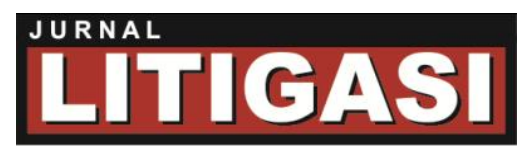

Available online at: http://ejournal.unpas.ac.id/index.php/litigasi

Litigasi, Vol. 16(2), 2015, 2975-3010

DOI: http://dx.doi.org/10.23969/litigasi.v16i2.44

\title{
PENGEMBALIAN ASET TINDAK PIDANA KORUPSI MENURUT SISTEM HUKUM INDONESIA DALAM MEWUJUDKAN NEGARA HUKUM KESEJAHTERAAN
}

\section{Haswandi}

Mahasiswa Program Doktor IImu Hukum Fakultas Hukum Universitas Andalas Padang, Jl. Pancasila No.10 Padang, Telp.0751-27404. Hp.081315003682, Email: haswandihaswandi@yahoo.co.id.

\begin{abstract}
ABSTRAK
Perangkat hukum pidana dalam mengembalikan aset hasil tindak pidana korupsi pada saat ini mengalami kekeliruan paradigma karena hanya mengandalkan uang pengganti kejahatan korupsi yang terkandung dalam Pasal 18 Undang-Undang Nomor 31 Tahun 1999 Tentang Pemberantasan Tindak Pidana Korupsi sebagaimana telah diubah dengan Undang-Undang Nomor 20 Tahun 2001, di mana Pengembalian harta atau kekayaan hanya ditujukan kepada terpidana. Padahal modus menyembunyikan harta kekayaan hasil korupsi biasanya dengan menggunakan sanak keluarga, kerabat dekat atau orang kepercayaannya termasuk para ahli warisnya. Hambatan pengembalian aset tindak pidana korupsi disebabkan belum efektifnya gugatan perdata sebagai sarana untuk mengembalikan aset hasil kejahatan korupsi, kelembagaan penegak hukum, belum efektifnya Ratifikasi UNCAC 2003 dilaksanakan dalam hukum Indonesia, serta kelemahan di ranah regulasi tindak pidana korupsi. Konsep hukum mendatang dalam pengembalian aset tindak pidana korupsi pelaku dan ahli warisnya dalam mewujudkan negara hukum kesejahteraan, setidaknya ditempuh dalam beberapa langkah hukum progresif, yakni perbaikan regulasi peraturan perundang-undangan, optimalisasi Bantuan Hukum Timbal Balik, Perluasan kewenangan Komisi Pemberantasan Korupsi dalam Pengembalian Aset hasil tindak pidana korupsi, Penguatan koordinasi antar lembaga penegak hukum, serta menyegerakan menyelesaikan UndangUndang Pengembalian Aset.
\end{abstract}

Kata Kunci: Pengembalian; Aset Korupsi; Ahli Waris

Copyright @ 2015, LITIGASI, p-ISSN: 0853-7100; e-ISSN: 2442-2274 
Available online at: http://ejournal.unpas.ac.id/index.php/litigasi

Litigasi, Vol. 16(2), 2015, 2975-3010

DOI: http://dx.doi.org/10.23969/litigasi.v16i2.44

\begin{abstract}
Criminal laws regulating asset recovery of corruption today experience a paradigm oversight since it only relies on the money substitute in corruption under Article 18 of Law No. 31, 1999 concerning The Eradication of The Crime of Corruption as amended with the Law No. 20, 2001 in which asset recovery is addressed only to the convict. In fact, modus to cover up the proceed of corruption usually involves the family, close relatives or confidants including the heirs. The obstacle in recovering the asset is that civil lawsuit is not yet effective as the means to recover the asset, the organization of law enforcement, the ratification of 2003 UNCAC that is also not yet effectively implemented in Indonesian law, and the laws against corruption that are weak. Future concept of law in asset recovery of proceed of corruption by the culprit and the heirs in order to materialize a legal welfare state should at least done through progressive laws i.e. reformation of law, optimization of Mutual Legal Assistance, the widening of authority implemented by the Eradication Commission of Corruption in recovering the asset as the proceed of corruption, the strong inter-agency coordination of law enforcements, and the urgency to promulgate the Recovery Asset Act.
\end{abstract}

Keyword: Recovery; Proceed of Corruption; Heirs

Copyright @ 2015, LITIGASI, p-ISSN: 0853-7100; e-ISSN: 2442-2274 
Available online at: http://ejournal.unpas.ac.id/index.php/litigasi

Litigasi, Vol. 16(2), 2015, 2975-3010

DOI: http://dx.doi.org/10.23969/litigasi.v16i2.44

\section{PENDAHULUAN}

Korupsi telah menjadi masalah global antar negara. Dalam

Resolusi "corruption in Government" (Hasil Kongres PBB ke-8 Tahun 1990) dinyatalan bahwa korupsi tidak hanya terkait dengan berbagai kegiatan "economic Crime", tetapi juga dengan "Organized Crime", illicit drug trafficking, money laundering, political crime, top hat crime, dan bahkan transnational crime. Bahkan Menurut Elwi Danil, aparat penegak hukum relatif tidak berdaya, atau tidak mempunyai kekuatan untuk menghadapi jenis tindak pidana ini (Elwi Danial, 2001: 2). Dalam perkembangan saat ini pemberantasan korupsi difokuskan kepada tiga isu pokok, yaitu pencegahan, pemberantasan dan pengembalian aset hasil korupsi/asset recovery. Pengertian Pengembalian aset (asset forfeiture) dibedakan dari pengertian pengembalian aset (asset recovery) yang diatur dalam bab V Konvensi PBB anti korupsi tahun 2003. Bab V tersebut memberikan pengertian asset recovery mulai dari pencegahan dan deteksi transfer Aset Tindak Pidana (ATP); (1) langkah hukum pengembalian ATP secara langsung, (2) mekanisme pengembalian ATP melalui kerjasama internasional penyitaan, (3) kerjasama internasional untuk tujuan penyitaan, (4) pengembalian dan pencairan ATP (Romli Atmasasmita, 2014).

Perkembangan itu bermakna, pemberantasan korupsi tidak hanya terletak pada upaya pencegahan maupun pemidanaan para koruptor saja tetapi juga meliputi tindakan yang dapat mengembalikan kerugian keuangan negara akibat dari kejahatan extraordinary tersebut. Menurut

Copyright $\odot$ 2015, LITIGASI, p-ISSN: 0853-7100; e-ISSN: 2442-2274 
Saldi Isra, kegagalan pengembalian aset hasil korupsi dapat mengurangi makna penghukuman para koruptor (www.saldiisra.com).

Upaya pengembalian aset negara yang dicuri (stolen asset recovery) melalui tindak pidana korupsi (tipikor) cenderung tidak mudah untuk dilakukan. Para pelaku tipikor memiliki akses yang luar biasa luas dan sulit dijangkau dalam menyembunyikan maupun melakukan pencucian uang (money laundering) hasil tindak pidana korupsinya. Permasalahan menjadi semakin sulit untuk upaya recovery dikarenakan tempat penyembunyian (safe haven) hasil kejahatan tersebut yang melampaui lintas batas wilayah negara dimana tindak pidana korupsi itu sendiri dilakukan (www.saldiisra.com).

Berkaitan dengan pengaturan pengembalian aset tersebut di atas, pemerintah Indonesia telah menerbitkan berbagai peraturan yang dapat dijadikan sebagai dasar/landasan dalam upaya pemerintah untuk mengembalikan kerugian keuangan negara sebagai akibat dari tindak pidana korupsi. Upaya-upaya dimaksud antara lain diatur dalam :

1. Undang-Undang Nomor 31 Tahun 1999 sebagaimana diubah dengan Undang-Undang Nomor 20 Tahun 2001 Tentang Pemberantasan Tindak Pidana Korupsi (UU Korupsi);

2. Undang-Undang Nomor 7 Tahun 2006 Tentang Pengesahan United Nations Convention Against Corruption (Konvensi Anti Korupsi);

3. Undang-Undang Nomor 15 Tahun 2002 sebagaimana diubah dengan Undang-Undang Nomor 25 Tahun 2003 Tentang Tindak Pidana Pencucian 
Available online at: http://ejournal.unpas.ac.id/index.php/litigasi

Litigasi, Vol. 16(2), 2015, 2975-3010

DOI: http://dx.doi.org/10.23969/litigasi.v16i2.44

Uang (UU TPPU)dan terakhir diubah dengan Undang-Undang Nomor 8

Tahun 2010 Tentang Tindak Pidana Pencucian Uang ;

4. Undang-Undang Nomor 1 Tahun 2006 Tentang Bantuan Timbal Balik Dalam Masalah Pidana.

Undang-Undang Nomor 31 Tahun 1999 Tentang Pemberantasan Tindak Pidana Korupsi sebagaimana telah diubah dengan Undang-Undang Nomor 20 Tahun 2001 Tentang Perubahan Atas Undang-Undang Nomor 31 Tahun 1999 Tentang Pemberantasan Tindak Pidana Korupsi (UU PTPK) merupakan istrumen utama pemberantasan tindak pidana korupsi di Indonesia. Instrumen perundangundangan baik langsung maupun tidak langsung yang digunakan sebagai landasan dalam pemberantasan tindak pidana korupsi di Indonesia saat ini adalah: TAP MPR No. XI Tahun 1998 Tentang Penyelcnggaraan Negara Yang Bebas KKN; UU No. 11 Tahun 1980 Tentang Tindak Pidana Suap; UU No. 31 Tahun 1999 Tentang Pemberantasan TPK; UU No. 20 Tahun 2001 tentang Perubahan Atas UU No. 3! Tahun 1999 tentang Pemberantasan TPK; UU No. 30 Tahun 2002 tentang KPK; UU No 7 Tahun 2006 Tentang Pengesahan Konvensi Perserikatan Bangsa-Bangsa Anti Korupsi, 2003; UU No 1 Tahun 2006 Tentang Bantuan Timbal Balik Masalah Pidana; UU No. 46 Tahun 2009 Tentang Pengadilan TPK; dan UU No. 8 Tahun 2010 Tentang Pencegahan dan Pemberantasan Tindak Pidana Pencucian Uang. Dalam undang-undang ini ketentuan tentang pertanggungjawaban pelaku tindak pidana korupsi atau ahli warisnya dapat

Copyright @ 9 2015, LITIGASI, p-ISSN: 0853-7100; e-ISSN: 2442-2274 
Available online at: http://ejournal.unpas.ac.id/index.php/litigasi

Litigasi, Vol. 16(2), 2015, 2975-3010

DOI: http://dx.doi.org/10.23969/litigasi.v16i2.44

ditemukan dalam Pasal 32, Pasal 33, dan Pasal 34 Undang-Undang No. 31 Tahun 1999 Tentang Pemberantasan Tindak Pidana Korupsi.

Pasal 32 menyebutkan sebagai berikut: (1) Dalam hal penyidik menemukan dan berpendapat bahwa satu atau lebih unsur tindak pidana korupsi tidak dapat cukup bukti, sedangkan secara nyata telah ada kerugian keuangan negara maka penyidik segera menyerahkan berkas perkara hasil penyidikan tersebut kepada Jaksa Pengacara Negara untuk dilakukan gugatan perdata atau diserahkan kepada instansi yang dirugikan untuk mengajukan gugatan. (2) Putusan bebas dalam perkara tindak pidana korupsi tidak menghapuskan hak untuk menuntut keruguan terhadap keuangan negara. Pasal 33 menyebutkan sebagai berikut: "Dalam hal tersangka meninggal dunia pada saat dilakukan penyidikan, sedangkan secara nyata telah ada kerugian keuangan negara, maka penyidik segera menyerahkan berkas perkara hasik penyidikan tersebut kepada Jaksa Pengacara Negara atau diserahkan kepada instansi yang dirugikan untuk dilakukan gugatan perdata terhadap ahli warisnya". Pasal 34 menyebutkan sebagai berikut: "Dalam hal terdakwa meninggal dunia pada saat dilakukan pemeriksaan disidang pengadilan, sedangkan secara nyata telah ada kerugian keuangan negara maka penuntut umum segera menyerahkan salinan berkas berita acara sidang tersebut kepada Jaksa Pengacara Negara atau diserahkan kepada instansi yang dirugikan untuk dilakukan gugatan perdata terhadap ahli warisnya".

Undang-undang tindak pidana korupsi tersebut, pengembalian kerugian keuangan negara dapat dilakukan melalui dua instrumen hukum yaitu instrumen

Copyright @ 9 2015, LITIGASI, p-ISSN: 0853-7100; e-ISSN: 2442-2274 
Available online at: http://ejournal.unpas.ac.id/index.php/litigasi

Litigasi, Vol. 16(2), 2015, 2975-3010

DOI: http://dx.doi.org/10.23969/litigasi.v16i2.44

hukum pidana dan instrumen hukum perdata. Instrumen hukum pidana dilakukan oleh penyidik dengan menyita harta benda milik pelaku yang selanjutnya diputus pengadilan dengan putusan pidana tambahan berupa uang pengganti kerugian keuangan negarasetelah penuntut umum menuntut agar harta benda milik pelaku tersebut dirampas oleh hakim. Sementara instrument perdata (melalui Pasal 32, 33, 34) yang dilakukan oleh Jaksa Pengacara Negara (JPN) atau instansi yang dirugikan.

Upaya pengembalian kerugian keuangan negara yang menggunakan intrumen perdata, sepenuhnya tunduk pada disiplin hukum perdata materiil maupun formil, meskipun berkaitan dengan tindak pidana korupsi. Pengembalian aset tindak pidana melalui keperdataan berasal dari perkembangan praktik penegakan hukum pidana di Inggris dan Amerika Serikat menghadapi hambatanhambatan di mana aset digunakan sebagai sarana untuk melakukan tindak pidana atau sebagai penunjang kesinambungan aktivitas organisasi kejahatan. Dasar pemikiran tersebut berasal dari konsep pemikiran sistem hukum common law yaitu pengertian forfeiture itu sendiri mengandung arti; “a piece of property guilty of wrong doing" dan konsekuensinya, harta benda tersebut dapat dirampas sebagai suatu hukuman atas suatu tindak pidana dimana harta benda tersebut digunakan untuk melakukan tindak pidana tersebut atau berkaitan dengan tindap pidana tersebut (Romli Atmasasmita, 2014).

Berbeda dengan proses pidana yang menggunakan sistem pembuktian materiil, maka proses perdata menganut sistem pembuktian formil yang dalam

Copyright $\odot$ 2015, LITIGASI, p-ISSN: 0853-7100; e-ISSN: 2442-2274 
Available online at: http://ejournal.unpas.ac.id/index.php/litigasi

Litigasi, Vol. 16(2), 2015, 2975-3010

DOI: http://dx.doi.org/10.23969/litigasi.v16i2.44

praktiknya bisa lebih sulit daripada pembuktian materiil. Dalam tindak pidana korupsi khususnya selain penuntut umum maka, terdakwa juga mempunyai beban pembuktian, yaitu terdakwa wajib membuktikan bahwa harta benda miliknya diperoleh bukan karena korupsi. Beban pembuktian pada terdakwa ini dikenal dengan asas Pembalikan Beban Pembuktian (Reversal Burden of Proof). Asas ini mengandung bahwa kepada tersangka atau terdakwa sudah dianggap bersalah melakukan tindak pidana korupsi (Presumption of Guilt), kecuali jika ia mampu membuktikan bahwa dirinya tidak melakukan tindak pidana korupsi dan tidak menimbulkan kerugian keuangan negara.

Permasalahan yang dihadapi saat ini adalah sistem penegakan hukum di Indonesia terutama peraturan perundang-undangan baik yang berkaitan dengan hukum materiil maupun hukum acaranya belum dapat memaksimalkan pengembalian aset tersebut.

Mekanisme perdata dalam pengembalian aset secara teknis-yuridis terdapat beberapa kesulitan yang akan dihadapi jaksa pengacara negara atau instansi yang dirugikan dalam melakukan gugatan perdata. Antara lain, hukum acara perdata yang digunakan masih tunduk pada hukum acara perdata zaman kolonial yang masih menganut asas pembuktian formal. Beban pembuktian terletak pada pihak yang mendalilkan (Pasal 1865 KUH Perdata dan Pasal 163 HIR serta Pasal 283 Rbg) jaksa pengacara negara atau instansi yang dirugikan yang harus membuktikan, kesetaraan para pihak, kewajiban hakim untuk mendamaikan para pihak, dan sebagainya. Sedangkan jaksa pengacara negara (JPN) atau instansi

Copyright $\odot$ 2015, LITIGASI, p-ISSN: 0853-7100; e-ISSN: 2442-2274 
Available online at: http://ejournal.unpas.ac.id/index.php/litigasi

Litigasi, Vol. 16(2), 2015, 2975-3010

DOI: http://dx.doi.org/10.23969/litigasi.v16i2.44

yang dirugikan sebagai penggugat harus membuktikan secara nyata bahwa telah ada kerugian negara yakni kerugian keuangan negara akibat atau berkaitan dengan perbuatan melawan hukum yang dilakukan tersangka, terdakwa, atau terpidana, adanya harta benda milik tersangka, terdakwa, atau terpidana berupa hasil tindak pidana korupsi yang dapat digunakan untuk pengembalian kerugian keuangan negara, selain itu seperti umumnya penanganan kasus perdata, membutuhkan waktu yang relatif panjang sampai ada putusan hukum yang berkekuatan hukum tetapbahkan setelah itu ada lagi upaya hukum luar biasa seperti peninjauan kembali. Belum lagi halangan karena pada saat akan di eksekusi muncul gugatan perlawanan atau bantahan dari pihak ketiga (derden verzet) terhadap harta yang akan dieksekusi.

Hal ini akan menyulitkan proses penegakan hukum perdata karena negara sebagai penggugat harus mempunyai bukti yang kuat untuk membuktikan tergugat adalah pelaku tindak pidana korupsi serta pembuktian tentang berapa besarnya kerugian negara akibat korupsinya tersebut setelah terjadinya proses hukum dalam ruang lingkup hukum pidana sebagaimana tersirat dalam ketentuan Pasal 32, Pasal 33, Pasal 34, Pasal 18 ayat (1) huruf b Undang-Undang No. 31 Tahun 1999 dan Pasal 38 C Undang-Undang No. 20 Tahun 2001 Tentang Perubahan atas Undang-Undang Nomor 31 Tahun 1999 Tentang Pemberantasan Tindak Pidana Korupsi.

Keadaan-keadaan tersebut semakin rumit jika pelakunya meninggal dunia sebelum diputus oleh pengadilan dan ahli warisnya secara tegas membuat

Copyright @ 9 2015, LITIGASI, p-ISSN: 0853-7100; e-ISSN: 2442-2274 
Available online at: http://ejournal.unpas.ac.id/index.php/litigasi

Litigasi, Vol. 16(2), 2015, 2975-3010

DOI: http://dx.doi.org/10.23969/litigasi.v16i2.44

pernyataan dikepaniteraan pengadilan negeri menolak sebagai pewaris (Pasal 833 ayat (1) KUH Perdata jo Pasal 1057 KUH Perdata jis Pasal 1058 KUH Perdata) atau harta hasil korupsinya tersebut disembunyikan diluar negeri atau disembunyikan melalui agen, notaris, pengacara, keluarga atau orang-orang dekat dengan pelaku tindak pidana korupsi tersebut yang dalam dunia hukum dikenal dengan "Gate Keeper".

Kelemahan lain dalam Undang-Undang Tindak Pidana Korupsi yang ada sekarang berkaitan dengan pengembalian aset atau harta kekayaan pelaku tindak pidana korupsi adalah adanya ketentuan Pasal 18 ayat (3) yang menyebutkan sebagai berikut: Dalam hal terpidana tidak mempunyai harta benda yang mencukupi untuk membayar uang pengganti sebagaimana yang dimaksud dalam ayat (1) huruf $b$ maka dipidana dengan pidana penjara yang lamanya tidak melebihi ancaman maksimum dari pidana pokoknya sesuai dengan ketentuan dalam undang undang ini lamanya pidana tersebut sudah ditentukan dalam putusan pengadilan.

Berdasarkan ketentuan Pasal 18 ayat (3) tersebut di atas maka hakim dalam putusannya dapat mengganti hukuman pembayaran uang pengganti dengan pidana penjara yang lamanya ditentukan dalam putusan tersebut. Dalam praktik banyak terpidana yang lebih memilih untuk melaksanakan hukuman penjara pengganti daripada membayar atau mengembalikan uang hasil korupsinya kepada negara karena berhasil menyembunyikan aset hasil korupsinya tersebut sedangkan negara membutuhkan dana untuk pembangunan dan untuk menyejahterakan

Copyright @ C 2015, LITIGASI, p-ISSN: 0853-7100; e-ISSN: 2442-2274 
Available online at: http://ejournal.unpas.ac.id/index.php/litigasi

Litigasi, Vol. 16(2), 2015, 2975-3010

DOI: http://dx.doi.org/10.23969/litigasi.v16i2.44

masyarakat sebagai wujud dari tujuan negara yang tercantum dalam alinea ke IV Pembukaan Undang-Undang Dasar Negara Republik Indonesia Tahun 1945.

Disisi lain muncul lagi permasalahan bagaimana jika terpidana hanya membayar sebagian saja dari hukuman pembayaran uang pengganti tersebut sedangkan lamanya hukuman penjara pengganti telah ditetapkan dalam putusan hakim. Secara yuridis apakah dapat secara otomatis hukuman penjara penggantinya disesuaikan persentasenya dengan jumlah uang pengganti kerugian yang telah dibayar oleh terpidana tindak pidana korupsi ataukah pembayaran berdasarkan besarnya persentase harus disebutkan terlebih dahulu dalam amar putusan hakim terhadap hal ini undang-undang belum mengaturnya.

Berdasarkan uraian diatas dapat dikemukakan beberapa permasalahan sebagai berikut:

1. Bagaimana proses dan penanganan pengembalian aset tindak pidana korupsi pelaku dan ahli warisnya dalam ruang lingkup hukum pidana maupun dalam ruang lingkup hukum perdata yang dapat mewujudkan negara hukum kesejahteraan di Indonesia.

2. Apakah yang menjadi hambatan dan kendala pengembalian aset tindak pidana korupsi dari pelaku dan ahli warisnya dalam sistem hukum Indonesia.

3. Bagaimanakah konsep hukum mendatang dalam pengembalian aset tindak pidana korupsi pelaku dan ahli warisnya dalam mewujudkan negara hukum kesejahteraan.

Copyright $\odot$ 2015, LITIGASI, p-ISSN: 0853-7100; e-ISSN: 2442-2274 
Available online at: http://ejournal.unpas.ac.id/index.php/litigasi

Litigasi, Vol. 16(2), 2015, 2975-3010

DOI: http://dx.doi.org/10.23969/litigasi.v16i2.44

\section{PEMBAHASAN}

A. Proses dan Penanganan Pengembalian Aset Tindak Pidana Korupsi Pelaku dan Ahli Warisnya dalam Ruang Lingkup Hukum Pidana dan Hukum Perdata

Substansi sistem hukum pengembalian aset melalui jalur hukum pidana umumnya terdiri dari ketentuan-ketentuan mengenai proses pengembalian aset melalui 4 tahap yang terdiri dari (Purwaning M. Yanuar, 2007: 206);

1) Pelacakan aset;

2) Tidakan-tindakan pencegahan untuk menghentikan perpindahan aset-aset melalui mekasisme pembekuan;

3) Penyitaan;

4) Penyerahan aset dari negara penerima kepada negara korban tempat aset diperoleh secara tidak sah.

Tindakan pengembalian aset hasil tindak pidana korupsi sebagai upaya meminimalisasi kerugian negara yang disebabkan oleh tindak pidana korupsi merupakan upaya yang tidak kalah penting dibanding pemberantasan tindak pidana korupsi dengan memvonis pelaku dengan hukuman yang seberatberatnya. Pengembalian aset hasil tindak pidana korupsi untuk meminimalkan kerugian negara tersebut disamping harus dilakukan sejak awal proses penanganan perkara juga mutlak dilakukan melalui kerjasama dengan berbagai lembaga negara yang juga harus difasilitasi dengan bantuan intelijen keuangan (Suraji, Buguati, Sutriya, 2008: 9). Tahap pertama dari proses dan penembalian aset tindak pidana korupsi adalah tahap pelacakan aset. Tahap ini

Copyright @ C 2015, LITIGASI, p-ISSN: 0853-7100; e-ISSN: 2442-2274 
Available online at: http://ejournal.unpas.ac.id/index.php/litigasi

Litigasi, Vol. 16(2), 2015, 2975-3010

DOI: http://dx.doi.org/10.23969/litigasi.v16i2.44

merupakan tahap dimana dikumpulkannnya informasi mengenai aset yang di korupsi dan alat-alat bukti. Untuk menjadi lingkup dan arah tujuan investigasi menjadi fokus, menurut John Conyngham, otoritas yang melakukan investigasi atau melacak aset-aset tersebut bermitra dengan firma-firma hukum dan firma akuntansi (Suraji, Buguati, Sutriya dalam John Conyngham, 2002: 2). Untuk kepentingan investigasi dirumuskan praduga bahwa pelaku tindak pidana akan mengunakan dana-dana yang diperoleh secara tidak sah untuk kepentingan pribadi dan keluarganya (Suraji, Buguati, Sutriya dalam John Conyngham, 2002: 2).

Tahap kedua adalah tahap pembekuan aset. Kesuksesan investigasi dalam melacak aset-aset yang diperoleh secara tidak sah memungkinkan pelaksanan tahap berikutnya, yaitu pembekuan atau perampasan asset (Suraji, Buguati, Sutriya dalam John Conyngham, 2002: 2). Menurut United Nation Convention Againts Corruption (UNCAC) 2003, pembekuan berarti larangan sementara untuk mentransfer, mengkonversi, mendisposisi, atau memindahkan kekayaan atau untuk sementara dianggap sebagai ditaruh di bawah perwalian atau di bawah pengawasan berdasarkan perintah pengadilan atau badan yang berwenang lainnya (Suraji, Buguati, Sutriya dalam John Conyngham, 2002: 2). Mengingat tindak pidana korupsi merupakan salah satu kejahatan transnational yang tidak jarang terjadi melibatkan negara lain karena aset hasil korupsi disimpan di negara lain maka kerjasama antar negara dalam proses pengembalian aset sangat perlu diperhatikan. Jika aset-aset yang dikorupsi

Copyright @ C 2015, LITIGASI, p-ISSN: 0853-7100; e-ISSN: 2442-2274 
Available online at: http://ejournal.unpas.ac.id/index.php/litigasi

Litigasi, Vol. 16(2), 2015, 2975-3010

DOI: http://dx.doi.org/10.23969/litigasi.v16i2.44

berada di luar yurisdiksi negara korban. Negara korban merupakan negara diman seorang koruptor melakukan tindak pidana korupsi yang merugikan keuangan Negara' maka pelaksanaan perintah pembekuan dan pengembalian hanya dapat dilakukan melalui otoritas yang berkompeten dari negara penerima (Purwaning M. Yanuar, 207: 211).

Ada dua kemungkinan cara melaksanakan perintah pembekuan atau Pengembalian dari negara korban dalam yuridikasi hukum negara penerima.Negara penerima merupakan negara dimana para koruptor di negara kornan mengamankan hasil dari tindak pidana korupsi. Jika hukum nasional negara penerima mengizinkanbadan yang berwenang negara tersebut melaksanakan perintah pembekuan dan pengembalian yang dikeluarkan oleh badan yang berwenang lain tempat asal aset diperoleh secara tidak sah, perintah dari badan yang berwenenang negara korban dapat langsung dilaksanakan. Salah satu syarat penting untuk melaksanaan pengembalian oleh badan yang berwenang di negara penerima adalah bahwa aset-aset tersebut merupakan pengamanan sebelum dilakukan penyitaan untuk selanjutnya dapat dilakukan penyerahan aset dari negara penerima kepada negara korban (Purwaning M. Yanuar, 2007: 215).

Tahap ketiga adalah penyitaan aset-aset. Penyitaan merupakan perintah pegadilan atau badan yang berwenang untuk mencabut hak-hak pelaku tindak pidana korupsi atas aset-aset hasil tindak pidana korupsi. Biasanya perintah penyitaan dikeluarkan oleh pengadilan atau badan yang berwenang dari negara

Copyright $\odot$ 2015, LITIGASI, p-ISSN: 0853-7100; e-ISSN: 2442-2274 
Available online at: http://ejournal.unpas.ac.id/index.php/litigasi

Litigasi, Vol. 16(2), 2015, 2975-3010

DOI: http://dx.doi.org/10.23969/litigasi.v16i2.44

penerima setelah ada putusan pengadilan yang menjatuhkan pidana pelaku tindak pidana (Purwaning M. Yanuar, 2007: 215).

Menurut Pasal 54 ayat (1) UNCAC 2003, penyitaaan dapat dilakukan tanpa adanya putusan pengadilan dalam hal pelaku tindak pidana telah meninggal atau menghilang atau tidak ada kemungkinan bagi jaksa selaku penuntut umum melakukan penuntutan(United Nation Convention Againts Corruption (UNCAC) 2003 Pasal 54 (1)). Tahap penyitaan dijustifkasi oleh prisip yang berakar pada hukum yang menetapkan bahwa orang dilarang mendaptkan keuntungan dari kegiatan yang tidak berdasarkan hukum pada umumnya, dan tindak pidana, khususnya.

Prinsip ini mengikuti syarat bahwa jika hukum adalah untuk mempengaruhi tingkah laku orang, hukum itu harus menyampaikan pesanpesan yang koheren. Pesan-pesan ini tidak lagi koheren ketika pada satu sisi berusaha utuk mencegah bentuk khusus tingkah laku, tetapi pada sisi yang lain membiarkan seseorang yang melakukan bentuk khusus tingkah laku yang berusaha dicegah tersebut, mendapatkan keuntungan. Dengan demikian tindakan penyitaan terhadap aset hasil tindak pidana korupsi dibenarkan dengan landasan pemikiran bahwa hukum pidana harus tetap komit untuk tidak memberikan keuntungan kepada pelaku tidak pidana.

Setiap dugaan korupsi yang sedang diperiksa di Pengadilan asetnya harus disita terlebih dahulu, hal ini merupakan tindakan pengamanan agar aset hasil korupsi tersebut tidak dibawa pergi atau disembunyikan oleh pelaku.

Copyright @ C 2015, LITIGASI, p-ISSN: 0853-7100; e-ISSN: 2442-2274 
Available online at: http://ejournal.unpas.ac.id/index.php/litigasi

Litigasi, Vol. 16(2), 2015, 2975-3010

DOI: http://dx.doi.org/10.23969/litigasi.v16i2.44

Aset hasil korupsi harus disita terlebih dahulu agar kemudian setelah putusan bersalah oleh Hakim berkekuatan hukum tetap, aset hasil tidak pidana korupsi yang disita dapat dikembalikan kepada Negara. Tahap penyitaan merupakan tahap yang paling penting dalam rangkaian pengembalian aset hasil tindak pidana korupsi.Tujuan utama dari penyitaan adalah untuk kepentingan pembuktian dimuka sidang pengadilan, karena tanpa adanya barang bukti, perkara sulit diajukan ke hadapan sidang pengadilan. Baharuddin Lopa mengemukakan bahwa alangkah baiknya bila penyidik sebelum melakukan penyidikannya, terlebih dahulu melakukan pengamatan yang seksama atas semua kekayaan calon tersangka. Pada saat disidik langsung secepat nya kekayaan disita untuk menghindari pengalihan kekayaan kepada pihak ketiga. Jadi, yang terpenting ialah menyita kekayaan yang ada, bukan hanya menghitung berapa jumlah kerugian yang dikorupsi dan nanti jumlah itu diwajibkan baginya untuk membayar kembali kepada negara (Baharruddin Lopa, 2002: 54).

Tahap keempat dari rangkaian pengembalian aset hasil tindak pidana korupsi adalah penyerahan aset-aset hasil tindak pidana korupsi kepada korban atau negara korban.Agar dapat melakukan pengembalian aset-aset, baik negara penerima maupun negara korban perlu melakukan tindakan legislatif dan tindakan lainnya menurut prinsip-prinsip hukum nasional masing-masing negara sehingga badan yang berwenang dapat melakukan pengembalian aset-aset tersebut. Kebanyakan negara tidak mengatur secara khusus ketentuan 
Available online at: http://ejournal.unpas.ac.id/index.php/litigasi

Litigasi, Vol. 16(2), 2015, 2975-3010

DOI: http://dx.doi.org/10.23969/litigasi.v16i2.44

pembagian aset-aset yang dibekukan dan disita, sehingga pada umumnya masalah pembagian aset-aset ini yang diatur dalam perjanjian bantuan hukum timbal balik antara negara korban dengan negara penerima (Purwaning M. Yanuar, 2007: 233).

Pemerintah sudah memulai memperkenalkan upaya gugatan aset koruptor secara perdata melalui Undang-Undang Nomor 31 Tahun 1999 jo Undang-Undang Nomor 20 Tahun 2001 Tentang Tindak Pidana Korupsi (UU TIPIKOR). Menurut UU TIPIKOR, aparat penegak hukum (jaksa pengacara negara) atau instansi yang berwenang dapat menggugat aset koruptor secara perdata apabila telah terbukti adanya "kerugian negara", dan:

1. Tidak terdapat cukup bukti untuk membuktikan unsur-unsur pidana korupsi (putusan bebas tidak menghalangi upaya gugatan perdata) (Pasal 32 Undang-Undang Nomor 31 Tahun 1999);

2. Tersangka meninggal dunia (menggugat ke ahli warisnya) (Pasal 33 Undang-Undang Nomor 31 Tahun 1999);

3. Terdakwa meninggal dunia (menggugat ke ahli warisnya) (Pasal 34 Undang-Undang Nomor 31 Tahun 1999).

Jika dibandingakn dengan ICAR, yang mengemukakan bahwa penggunaan NCB dalam sejumlah kasus antara lain: (a) terdakwa sudah meninggal. Karena hukum pidana tradisional berfokus pada tanggung jawab seseorang dengan cara yang biasa untuk mengambil hasil-hasil kejahatan telah menjadi tindakan in persona. Ketika seseorang meninggal dan karena itu

Copyright @ C 2015, LITIGASI, p-ISSN: 0853-7100; e-ISSN: 2442-2274 
Available online at: http://ejournal.unpas.ac.id/index.php/litigasi

Litigasi, Vol. 16(2), 2015, 2975-3010

DOI: http://dx.doi.org/10.23969/litigasi.v16i2.44

kemungkinan untuk mengadili telah dipadamkan, secara tradisional ini berarti bahwa aset yang diperoleh secara ilegal tidak mungkin pulih. Karena dalam aksi rem pergi langsung terhadap aset sendiri, ini adalah obat sempurna dalam kasus tersebut; (b) terdakwa telah dibebaskan dalam sidang pidana dan penyitaan itu tidak mungkin. Sebuah melanjutkan Pengembalian non-keyakinan berdasarkan akan memungkinkan pemulihan theproceeds kejahatan. Hal ini seharusnya bukan merupakanupaya untuk "relitigasi" lanjutan, karena sidang ini tidak dimaksudkan untuk menetapkan kesalahan seseorang atau tanggung jawab, tetapi asal aset itu sendiri; (c) ada juga kasus di mana terdakwa tidak dapat ditemukan dalam yurisdiksi karena ia telah melarikan diri, karena ia sudah dipenjara di luar negeri atau untuk alasan lain; (d) pemilik asset tidak pasti. Pencucian uang biasanya mengikuti komisi kejahatan ekonomi untuk menyembunyikan asal-usul aset.Jika uang launderingprocess itu efektif bahkan kepemilikan bisa sulit untuk membuktikan. Dalam kasus ini non-keyakinan berbasis Pengembalian menjadi penting khusus; dan (e) undang-undang pembatasan mencegah bentuk pelanggaran sedang diselidiki. Di negara-negara dilanda korupsi ini adalah penting khusus, karena pejabat publik yang korup cenderung untuk tinggal di kantor selama beberapa tahun. (http://www.assetrecovery.org).

Penjelasan Pasal 38 C UU PTPK menjelaskan tujuan yang mendasari gugatan perdata pengembalian kerugian keuangan negara akibat tindak pidana korupsi, yaitu untuk memenuhi rasa keadilan masyarakat. Rasa keadilan

Copyright @ C 2015, LITIGASI, p-ISSN: 0853-7100; e-ISSN: 2442-2274 
Available online at: http://ejournal.unpas.ac.id/index.php/litigasi

Litigasi, Vol. 16(2), 2015, 2975-3010

DOI: http://dx.doi.org/10.23969/litigasi.v16i2.44

masyarakat ditekankan dalam penjelasan ini karena ditemukan banyak pelaku tindak pidana korupsi yang menyembunyikan harta yang diduga berasal dari tindak pidana korupsi. Gugatan perdata dengan demikian dilakukan untuk memenuhi rasa keadilan masyarakat. Hal ini karena apabila tidak dilakukan, maka akan menghambat pembangunan nasionaltidak tercapainya kesejahteraan masyarakat yang ideal, juga pertumbuhan dan kelangsungan pembangunan nasional yang menuntut efesiensi tinggi.

Gugatan perdata juga dimungkinkan apabila setelah putusan pengadilan memperoleh kekuatan hukum tetap, diketahui masih terdapat harta benda milik terpidana korupsi yang belum dikenakan Pengembalian. Pada kondisi ini, negara dapat melakukan gugatan perdata terhadap terpidana dan/atau ahli warisnya (Pasal 38 Undang-Undang Nomor 31 Tahun 1999).

Undang-undang tindak pidana korupsi mengatur 6 (enam) hal dalam kaitan dengan pengembalian kerugian keuangan negara, terdiri dari 5 (lima) meliputi gugatan perdata dan 1 (satu) melalui pidana tambahan yaitu:

1. Gugatan perdata pengembalian kerugian keuangan negara yang nyata disebabkan setelah dilakukan penyidikan ditemukan unsur tidak cukup bukti seperti diatur dalam Pasal 32 ayat (1) Undang-Undang Tindak Pidana Korupsi.

2. Gugatan perdata disebabkan karena adanya putusan bebas sedangkan secara nyata ada kerugian keuangan negara seperti diatur dalam Pasal 32 ayat (2) Undang-Undang Tindak Pidana Korupsi.

Copyright @ 2015 , LITIGASI, p-ISSN: 0853-7100; e-ISSN: 2442-2274 
Available online at: http://ejournal.unpas.ac.id/index.php/litigasi

Litigasi, Vol. 16(2), 2015, 2975-3010

DOI: http://dx.doi.org/10.23969/litigasi.v16i2.44

3. Gugatan perdata dalam hal tersangka meninggal dunia pada saat dilakukan penyidikan, sedangkan secara nyata telah ada kerugian keuangan negara seperti diatur dalam Pasal 33 Undang-Undang Tindak Pidana Korupsi.

4. Gugatan perdata dalam hal terdakwa meninggal dunia pada saat dilakukan pemeriksaan di sidang pengadilan sedangkan secara nyata telah ada kerugian keuangan negara seperti diatur dalam Pasal 34 Undang-Undang Tindak Pidana Korupsi.

5. Gugatan perdata terhadap tindak pidana korupsi yang telah mempunyai kekuatan hukum tetap tetapi masih terdapat harta benda yang diduga berasal dari tindak pidana korupsi yang belum dikenakan pengembalian kepada negara seperti diatur dalam Pasal 38 C Undang-Undang Tindak Pidana Korupsi

6. Pidana tambahan sebagaimana ditentukan dalam Pasal 18 ayat (1) Undang-Undang Tindak Pidana Korupsi.

Pengaturan gugatan perdata dalam tindak pidana korupsi menandai bahwa norma-norma hukum pidana saja tidak cukup memadai untuk pengembalian keuangan negara setidak-tidaknya dalam keadaan-keadaan tertentu.

Berdasarkan uraian di atas maka dimungkinkannya pengaturan gugatan perdata dalam undang-undang tindak pidana korupsi didasarkan kepada alasanalasan sebagai berikut:

Copyright $\odot$ 2015, LITIGASI, p-ISSN: 0853-7100; e-ISSN: 2442-2274 
Available online at: http://ejournal.unpas.ac.id/index.php/litigasi

Litigasi, Vol. 16(2), 2015, 2975-3010

DOI: http://dx.doi.org/10.23969/litigasi.v16i2.44

1. Penyelesaian perkara korupsi secara pidana tidak selalu berhasil mengembalikan secara maksimal kerugian keuangan negara, setidaktidaknya dalam keadaan tertentu. Keterbatasan hukum pidana menjadikan instrumen hukum pidana bukan satu-satunya untuk menyelesaikan masalah pengembalian keuangan negara akibat tindak pidana korupsi

2. Tindak pidana korupsi sebagai kejahatan yang bersifat ekstra ordinary crime yang melibatkan kekuasaan, kewenangan bahkan politik perlu penanganan yang luar biasa melalui jalur pidana maupun jalur perdata.

3. Tujuan pengaturan gugatan perdata dimaksudkan untuk memenuhi rasa keadilan masyarakat terhadap akibat tindak pidana korupsi guna memaksimalkan pengembalian keuangan negara yang dikorupsi pelaku.

B. Hambatan dan Kendala Pengembalian Aset Tindak Pidana Korupsi dari Pelaku dan Ahli Warisnya dalam Sistem Hukum Indonesia.

Saat ini, di Indonesia beberapa peraturan perundang-undangan memuat ketentuan-ketentuan hukum yang berkaitan dengan pengembalian hasil tindak pidana atau ganti kerugian antara lain adalah:

a. Undang-Undang Nomor 8 Tahun 1981 Tentang Kitab Undang-Undang Hukum Acara Pidana (KUHAP).

b. Undang-Undang Nomor 10 Tahun 1995 Tentang Kepabeanan sebagaimana telah diubah dengan Undang-Undang Nomor 17 Tahun 2006.

Copyright @ C 2015, LITIGASI, p-ISSN: 0853-7100; e-ISSN: 2442-2274 
Available online at: http://ejournal.unpas.ac.id/index.php/litigasi

Litigasi, Vol. 16(2), 2015, 2975-3010

DOI: http://dx.doi.org/10.23969/litigasi.v16i2.44

c. Undang-Undang Nomor 35 Tahun 2009 Tentang Narkotika.

d. Undang-Undang Nomor 19 Tahun 2004 Tentang Perpu Nomor 1 Tahun 2004 Tentang Perubahan Atas Undang-Undang Nomor 41 Tahun 1999 Tentang Kehutanan.

e. Undang-Undang Nomor 31 Tahun 1999 Tentang Pemberantasan Tindak Pidana Korupsi sebagaimana telah diubah dengan Undang-Undang Nomor 20 Tahun 2001.

f. Undang-Undang Nomor 8 Tahun 2010 Tentang Pencegahan dan Pemberantasan Tindak Pidana Pencucian Uang.

g. Undang-Undang Nomor 15 Tahun 2003 Tentang Pengesahan Peraturan Pemerintah Pengganti Undang-Undang Nomor 1 Tahun 2002 Tentang Pemberantasan Tindak Pidana Terorisme sebagai Undang-Undang.

Seluruh peraturan perundang-undangan tersebut di atas belum mengatur secara khusus mengenai lingkup pengertian istilah "asset recovery" sebagaimana tercantum dalam Bab V Konvensi Konvensi PBB Tahun 2003 (United Nations Convention Against Corruption UNCAC). Pengaturan mengenai penyitaan dan Pengembalian aset tindak pidana dalam peraturan perundang-undangan tersebut di atas terbatas pada dua model Pengembalian yaitu, "penyitaan terhadap barang yang digunakan untuk melakukan tindak pidana (instrumen sceleris) dan objek yang berhubungan dengan tindak pidana (objectum sceleris), sedangkan dalam peraturan perundang-undangan tersebut

Copyright @ 2015 , LITIGASI, p-ISSN: 0853-7100; e-ISSN: 2442-2274 
Available online at: http://ejournal.unpas.ac.id/index.php/litigasi

Litigasi, Vol. 16(2), 2015, 2975-3010

DOI: http://dx.doi.org/10.23969/litigasi.v16i2.44

di atas pengembalian terhadap hasil tindak pidana (fructum sceleris) belum diatur secara rinci dan memadai.

KUHAP (UU Nomor 8 Tahun 1981) sebenarnya tidak melarang gugatan perdata atas terjadinya hal-halyang menjadi dasar dakwaan dalam perkara pidana, namun tidak mengatur ketentuan mengenai acara gugatan perdata secara khusus. Hal ini sejalan dengan adanya ketentuan mengenai “Penggabungan Perkara Gugatan Ganti Kerugian” sebagaimana diatur oleh Pasal 98-101 KUHAP. Akan tetapi, yang perlu diperhatikan dalam gugatan perdata pada perkara tindak pidana korupsi haruslah didasarkan pada prinsipprinsip yang terkait di dalamnya, yaitu: Pertama, prinsip kondisional. Prinsip ini maksudnya bahwa gugatan perdata tidak selalu dapat diajukan dalam semua perkara tindak pidana korupsi tetapi, terbatas pada kondisi-kondisi tertentu. Kedua, prinsip gugatan perdata untuk jenis tindak pidana korupsi harus yang merugikan keuangan negara. Prinsip ini menunjukkan bahwa gugatan perdata tidak mencakup keseluruhan jenis tindak pidana korupsi yang diatur dalam UU PTPK. Gugatan perdata hanya terbatas pada tindak pidana korupsi yang menimbulkan kerugian keuangan negara, sebagaimana diatur dalam Pasal 2 ayat (1) dan Pasal 3 UU PTPK. Dan ketiga, prinsip gugatan perdata sebagai komplemen prosedur perampasan untuk negara. Berdasarkan ketentuan Pasal 38C UU PTPK memungkinkan dilakukan gugatan perdata khusus untuk hasil korupsi yang belum dilakukan perampasan untuk negara tersebut.

Copyright @ C 2015, LITIGASI, p-ISSN: 0853-7100; e-ISSN: 2442-2274 
Available online at: http://ejournal.unpas.ac.id/index.php/litigasi

Litigasi, Vol. 16(2), 2015, 2975-3010

DOI: http://dx.doi.org/10.23969/litigasi.v16i2.44

Namun sebagai mekanisme hukum acara, gugatan perdata dalam hal ini dilakukan untuk mengambil aset-aset hasil tindak pidana korupsi yang dikuasai oleh pelaku tindak pidana korupsi tetap melewati proses ajudikasi untuk mendapatkan keputusan pengadilan (perdata) yang ditetapkan oleh hakim. Tentunya tetap memiliki beberapa kelemahankelemahan yang ada seperti pada mekanisme perampasan aset berdasarkan putusan pidana.

Hambatan pengembalian aset dapat dijelaskan secara teoritik dan praktik. Secara teoritik, telah terjadi kekeliruan pemahaman dalam menyelesaikan masalah aset tindak pidana korupsi. Kekeliruan pertama, yaitu sikap apriori bahwa hukum pidana yang berorientasi pada filsafat keadilan retributif dipandang sebagai satu-satunya sarana hukum yang dianggap tepat untuk tujuan pemulihan kerugian keuangan negara. Sedangkan tujuan tersebut hanya dapat dicapai dengan perubahan paradigma baru yaitu keadilan korektifrehabilitatif dan restoratif. Kekeliruan kedua, selama ini pendekatan hukum dalam proses hukum pengembalian aset tindak pidana selalu menggunakan pendekatan hukum normatif yang berlandaskan positivisme hukum seharusnya selain memperhatikan aspek legal justice juga perlu diperhatikan sisi-sisi social justice dan morale justice.

C. Konsep Hukum Mendatang dalam Pengembalian Asset Tindak Pidana Korupsi

Gagasan mengenai pengembalian aset hasil tindak pidana korupsi tidak semata-mata untuk memiskinkan para koruptor sehingga mereka menderita,

Copyright @ C 2015, LITIGASI, p-ISSN: 0853-7100; e-ISSN: 2442-2274 
Available online at: http://ejournal.unpas.ac.id/index.php/litigasi

Litigasi, Vol. 16(2), 2015, 2975-3010

DOI: http://dx.doi.org/10.23969/litigasi.v16i2.44

tetapi Pengembalian aset hasil korupsi juga bertujuan sebagai tindakan preventif atau pencegahan tindak pidana korupsi. Dampak preventif pertama, terjadi pada tidak adanya aset-aset yang dikuasai oleh pelaku kejahatan sehingga para pelaku kehilangan sumber daya untuk melakukan kejahatan-kejahatan lainnya. Kedua, dengan menyerang langsung kepada motif kejahatan para pelaku korupsi, maka tidak ada lagi peluang untuk menikmati hasil dari tidak pidana itu ditiadakan setidaknya meminimalisasi. Pengembalian aset itu menghilangkan tujuan yang merupakan motif tindak pidana. Ketiadaan peluang mencapai tujuan itu dapat menghilangkan motif yang mendorong melakukan kejahatan.

Dampak preventif dari tindakan pengembalian aset ketiga, yakni dengan pengembalian aset ini pesan yang kuat apat diberikan kepada masyarakat luas bahwa tidak ada tempat yang aman di dunia ini bagi para pelaku tindak pidana untuk menyembunnyikan hasil tindak pidananya sekaligus memberikan pesan kuat bahwa tidak ada seorangpun yang dapat menikmati aset hasil tindak pidana sebagaimana doktrin "crime does not pay". Doktrin crime does not pay ini berisi pandangan bahwa seseorang tidak boleh mendapatkan keuntungan dari tindakan melanggar hukum umumnya, tindakan kejahatan pada khususnya. Pandangan ini mengikuti tuntutan bahwa jika hukum itu mempengaruhi tingkah laku orang, maka hukum itu memeberikan pesan-pesan koheren. Hal-hal ini memperlemah keinginan warga masyarakat, khususnya para pelaku potensial, untuk melakukan kejahatan (Badan Pembinaan Hukum Nasional Departemen Hukum dan Hak Asasi Manusia RI, 2009: 42).

Copyright (C) 2015, LITIGASI, p-ISSN: 0853-7100; e-ISSN: 2442-2274 
Available online at: http://ejournal.unpas.ac.id/index.php/litigasi

Litigasi, Vol. 16(2), 2015, 2975-3010

DOI: http://dx.doi.org/10.23969/litigasi.v16i2.44

Sebagaimana telah diuraikan diatas, bahwa sistem hukum Indonesia belum memiliki undang-undang atau ketentuan khusus perampasan aset hasil tindak pidana tanpa putusan pengadilan dalam perkara pidana. Saat ini, pengembalian aset dalam sistem hukum pidana Indonesia melalui putusan pengadilan yang telah memiliki kekuatan hukum tetap (inkracht). Kemudian dengan gugatan perdata seperti Pasal 33 UU No 31 Tahun 1999 Tentang Pemberantasan Tindak Pidana Korupsi sebagaimana telah diubah dengan $\underline{U U}$ No 20 Tahun 2001. Di samping itu, pengalaman pengembalian aset korupsi dari Negara-negara lain, serta hukum kebiasaan internasional yang telah berlaku di dalamnya, jelas bahwa ketentuan peraturan perundang-undangan dalam pemberantasan kejahatan termasuk korupsi dan pencucian uang yang berlaku di Indonesia saat ini belum cukup memadai jika ditujukan menyelamatkan aset-aset hasil kejahatan tersebut dari Negara lain untuk kepentingan sebesar-besarnya bagi kesejahteraan rakyat dan mengatasi kemiskinan.

Pusat Kajian Antikorupsi Fakultas Hukum Universitas Gadjah Mada bekerjasama dengan Kemitraan pada tahun 2008 melakukan kajian perihal Pengembalian Aset Kejahatan. Berdasarkan hasil kajian tersebut ada beberapa prasyarat dalam pengembalian aset kejahatan (Eddy O.S Hiariej, 2012). Pertama, kemauan politik negara. Pencurian aset seringkali bertalian dengan suatu rezim otoriter yang korup, sehingga untuk mengembalikan aset-aset yang telah dicuri, salah satu prasyarat yang dibutuhkan adalah kemauan politik

Copyright $\odot$ 2015, LITIGASI, p-ISSN: 0853-7100; e-ISSN: 2442-2274 
Available online at: http://ejournal.unpas.ac.id/index.php/litigasi

Litigasi, Vol. 16(2), 2015, 2975-3010

DOI: http://dx.doi.org/10.23969/litigasi.v16i2.44

negara, baik itu kemauan politik pemerintah, parlemen maupun lembaga yudikatif. Kemauan politik parlemen berkaitan dengan seperangkat aturan hukum yang harus disiapkan dalam rangka pengembalian aset, sedangkan kemauan politik pemerintah dan lembaga yudikatif dibutuhkan untuk mengambil langkah hukum dalam penegakan aturan tersebut. Pengalaman beberapa negara yang berhasil mengembalikan aset-aset yang telah dicuri oleh rezim yang korup dan otoriter menunjukkan kemauan politik negara yang sangat menentukan seperti di Filipina dalam pengembalian aset mantan presiden Ferdinand Marcos; di Nigeria dalam pengembalian aset mantan presiden Sani Abacha; di Peru dalam pengembalian aset mantan Kepala Intelijen Vladimiro Montesinos; dan di Zambia dalam pengembalian aset mantan presiden Frederick Jacob Titus Chiluba.

Kedua, sistem hukum. Terkait pengembalian aset, yang sangat dipentingkan adalah harmonisasi perundang-undangan dan sistem peradilan. Harmonisasi bertujuan agar tidak terjadi tumpang tindih antar berbagai undang-undang, karena dalam konteks Indonesia, kejahatan yang berpotensi mencuri aset negara mempunyai rezim hukum tersendiri sehingga proses penegakan hukum terhadap kejahatan-kejahatan tersebut berbeda antara satu dengan yang lain. Sebagai misal, pengembalian aset kejahatan korupsi perlu dilakukan harmonisasi mengingat proses penegakan hukum terhadap koruptor tidak hanya menjadi kewenangan Komisi Pemberantasan Korupsi semata tetapi juga menjadi kewenangan Kepolisian dan Kejaksaan. Oleh karena itu proses

Copyright @ $\odot$ 2015, LITIGASI, p-ISSN: 0853-7100; e-ISSN: 2442-2274 
Available online at: http://ejournal.unpas.ac.id/index.php/litigasi

Litigasi, Vol. 16(2), 2015, 2975-3010

DOI: http://dx.doi.org/10.23969/litigasi.v16i2.44

pengembalian aset kejahatan korupsi harus dilakukan secara efisien, efektif dan koordinatif di antara institusi penegak hukum yang memiliki kewenangan untuk itu dengan pembagian tugas yang proporsional dan profesional (Eddy O.S Hiariej, 2012).

Ketiga, kerjasama kelembagaan. Berkaitan dengan pengembalian aset kejahatan, kerjasama kelembagaan yang dimaksud adalah kerjasama antar lembaga-lembaga yudisial dan lembaga-lembaga ekstra yudisial. Hal ini karena pengembalian aset tidak selamanya berkaitan dengan kejahatan, dapat saja aset tersebut berada dalam rezim hukum keperdataan sehingga tidak menutup kemungkinan adanya gugatan pihak ketiga terhadap aset tersebut. Selain itu, tidak selamanya pula aset yang akan dikembalikan berwujud uang, deposito, giro atau sejenisnya, akan tetapi aset tersebut juga dapat berwujud benda termasuk di antaranya adalah tanah. Jika aset yang akan dikembalikan berwujud tanah, maka perlu adanya kerjasama dengan Badan Pertanahan Nasional. Jika aset yang dicuri kemudian 'dicuci' seolah-olah aset yang legal, maka kerjasama Pusat Pelaporan dan Analisis Transaksi Keuangan (PPATK) sangat dibutuhkan (Eddy O.S Hiariej, 2012).

Keempat, kerjasama internasional. Dalam rangka pengembalian aset kejahatan, kerjasama internasional mutlak diperlukan karena aset yang dicuri biasanya disimpan di luar wilayah teritorial Indonesia. Di samping itu pengembalian aset merupakan tujuan dan salah satu prinsip dalam United Nations Convention Against Corruption (UNCAC) yang telah diratifikasi 
Available online at: http://ejournal.unpas.ac.id/index.php/litigasi

Litigasi, Vol. 16(2), 2015, 2975-3010

DOI: http://dx.doi.org/10.23969/litigasi.v16i2.44

Indonesia dengan Undang-Undang Nomor 7 Tahun 2006 dengan tujuan utama kerjasama internasional dalam pemberantasan korupsi. Berkaitan dengan kerjasama internasional, paling tidak ada dua prinsip yang harus dipenuhi yaitu prinsip kepercayaan dan prinsip resiprokal. Prinsip kepercayaan didasarkan pada adagium omnia praesumuntur rite esse acta yang berarti adanya kepercayaan penuh bahwa di luar wilayah teritorial suatu negara semua telah ditetapkan secara benar atas dasar suatu kerjasama. Sedangkan prinsip resiprokal atau prinsip timbal balik adalah jika suatu negara mengharapkan perlakukan yang baik dari negara lain maka negara tersebut juga harus memberi perlakuan yang baik terhadap negara lain (Eddy O.S Hiariej, 2012). Untuk itu, kehadiran undang-undang pengembalian aset di Indonesia menjawab keempat persoalan di atas.

Mengutip pendapat Eddy O.S Hiariej, paling tidak ada enam alasan yang mendasari perlunya undang-undang pengembalian aset di Indonesia. Pertama, indeks prestasi korupsi di Indonesia cukup mencengangkan dalam beberapa tahun terakhir ini dan hanya bisa disamai oleh Mexico. Sudah barang tentu uang yang dikorupi sebagian besar tidak berputar di Indonesia tetapi dilarikan ke luar negeri. Kedua, Indonesia telah meratifikasi United Nations Convention Against Corruption (UNCAC) dengan Undang-Undang Nomor 7 Tahun 2006 yang mana asset recovery merupakan salah satu prinsip dasar dari konvensi tersebut. Konsekuensi lebih lanjut, Indonesia harus segera menghasilkan sejumlah peraturan perundang-undangan pelaksana (termasuk

Copyright @ C 2015, LITIGASI, p-ISSN: 0853-7100; e-ISSN: 2442-2274 
Available online at: http://ejournal.unpas.ac.id/index.php/litigasi

Litigasi, Vol. 16(2), 2015, 2975-3010

DOI: http://dx.doi.org/10.23969/litigasi.v16i2.44

undangundang pengembalian asset) sesuai dengan konvensi tersebut. Ketiga, Indonesia telah mengatur tentang mutual legal assistance dalam UndangUndang Nomor 1 Tahun 2006, yang mana salah satu prinsip dasarnya adalah asas resiprokal. Jika Indonesia menginginkan asetnya yang telah dicuri dan dibawa ke luar negeri dikembalikan, maka Indonesia pun harus mempunyai pengaturan yang jelas mengenai pengembalian aset yang juga menjamin pengembalian aset dari Negara lain yang disimpan di Indonesia (Eddy O.S Hiariej, 2013).

Keempat, Indonesia berperan aktif dalam Stolen Asset Recovery (StAR) Initiative yang mana dibutuhkan kerja sama internasional, baik bilateral, maupun multilateral dalam rangka pengembalian aset tersebut. Keberadaan undang-undang pengembalian aset, berdasarkan sejumlah instrumen hukum internasional maupun hukum nasional yang ada, merupakan suatu keniscayaan yang harus segera dibentuk sebagai bagian dari paket undang-undang anti korupsi. Kelima, banyak kejahatan yang terjadi di Indonesia dalam kurun waktu 10 tahun terakhir ini menimbulkan kerugian yang besar bagi keuangan negara, termasuk kejahatan-kejahatan yang menghasilkan asset yang cukup besar. Kejahatan-kejahatan yang asetnya menjadi ruang lingkup pengembalian aset adalah korupsi, pencucian uang, terorisme, perdagangan orang, penyelundupan senjata, narkotika, psikotropika, hak kekayaan intelektual, kepabeanan dan cukai, kehutanan serta perikanan (Eddy O.S Hiariej, 2013).

Copyright $\odot$ 2015, LITIGASI, p-ISSN: 0853-7100; e-ISSN: 2442-2274 
Available online at: http://ejournal.unpas.ac.id/index.php/litigasi

Litigasi, Vol. 16(2), 2015, 2975-3010

DOI: http://dx.doi.org/10.23969/litigasi.v16i2.44

Keenam, pengembalian aset merupakan salah satu "missing link" dalam upaya pemberantasan korupsi di Indonesia. Rumusan dan implementasi yang efektif tentang pengembalian aset hasil korupsi memiliki makna ganda bagi pemberantasan kejahatan korupsi di Indonesia. Pertama, implementasi yang efektif dari ketentuan tentang pengembalian aset tersebut akan membantu negara dalam upaya menanggulangi dampak buruk dari kejahatan korupsi. Kedua, adanya legislasi yang memuat klausula tentang pengembalian aset hasil kejahatan korupsi merupakan pesan jelas bagi para pelaku korupsi bahwa tidak ada lagi tempat untuk menyembunyikan harta kekayaan hasil kejahatan korupsi (no safe haven), baik harta kekayaan Indonesia yang dilarikan ke luar negeri maupun harta kekayaan luar negeri yang ada di Indonesia (Eddy O.S Hiariej, 2013).

Pengembalian aset tindak pidana korupsi secara maksimal melalui penegakan hukum pidana yang sekaligus dengan penegakan hukum perdata diharapkan akan dapat mewujudkan kesejahteraan bagi seluruh masyarakat Indonesia sebagaimana yang diamanatkan oleh alinea ke IV Pembukaan Undang-Undang Dasar Negara Republik Indonesia.

Copyright @ $\odot$ 2015, LITIGASI, p-ISSN: 0853-7100; e-ISSN: 2442-2274 
Available online at: http://ejournal.unpas.ac.id/index.php/litigasi

Litigasi, Vol. 16(2), 2015, 2975-3010

DOI: http://dx.doi.org/10.23969/litigasi.v16i2.44

\section{SIMPULAN DAN SARAN}

\section{A. SIMPULAN}

1. Perangkat hukum pidana dalam mengembalikan aset hasil tindak pidana korupsi pada saat ini mengalami kekeliruan paradigma karena hanya mengandalkan uang pengganti kejahatan korupsi yang terkandung dalam Pasal 18 Undang-Undang Nomor 31 Tahun 1999 Tentang Pemberantasan Tindak Pidana Korupsi sebagaimana telah diubah dengan Undang-Undang Nomor 20 Tahun 2001, di mana Pengembalian harta atau kekayaan hanya ditujukan kepada terpidana. Padahal modus menyembunyikan harta kekayaan hasil korupsi biasanya dengan menggunakan sanak keluarga, kerabat dekat atau orang kepercayaannya termasuk para ahli warisnya. Disisi lain, gugatan perdata diajukan setelah tindak pidana tidak memungkinkan lagi dilakukan, karena dihadapkan pada kondisi-kondisi tertentu sebagaimana dimaksud Pasal 32, 33, 34, 38C Undang-Undang Nomor 31 Tahun 1999 Tentang Pemberantasan Tindak Pidana Korupsi sebagaimana telah diubah dengan UndangUndang Nomor 20 Tahun 2001. Tanpa adanya pengaturan dalam undang-undang pemberantasan tindak pidana korupsi tidak memungkinkan untuk dilakukan gugatan perdata.

2. Gugatan perdata berdasarkan Pasal 33 dan Pasal 34 dengan demikian mensyaratkan adanya dua hal : (1) tersangka atau terdakwa meninggal dunia pada saat proses penyidikan atau pemeriksaan sidang pengadilan, 
Available online at: http://ejournal.unpas.ac.id/index.php/litigasi

Litigasi, Vol. 16(2), 2015, 2975-3010

DOI: http://dx.doi.org/10.23969/litigasi.v16i2.44

(2) secara nyata telah ada kerugian keuangan negara. Ketentuan Pasal 33

dan 34 UU PTPK menandai bahwa dengan cara apapun kerugian keuangan negara harus dikembalikan meskipun tersangka atau terdakwa meninggal dunia. Kondisi seperti menjadikan gugatan dapat ditujukan kepada ahli warisnya. UU PTPK secara eksplisit, selain mencantumkan syarat materiil dalam bentuk kerugian keuangan negara dan perbuatan melawan hukum juga menentukan syarat formil. Syarat formil dalam gugatan perdata berkaitan dengan kedudukan negara sebagai penggugat. Pemerintah dalam rangka menyelenggarakan kesejahteraan, perlindungan atas warga negaranya mempunyai hak untuk mengajukan gugatan secara perdata ke pengadilan (Legal Standing Pemerintah).

3. Hambatan pengembalian aset dapat dijelaskan secara teoritik dan praktik. Secara teoritik, telah terjadi kekeliruan pemahaman dalam menyelesaikan masalah aset tindak pidana korupsi. Kekeliruan pertama, yaitu sikap apriori bahwa hukum pidana yang berorientasi pada filsafat keadilan retributif dipandang sebagai satu-satunya sarana hukum yang dianggap tepat untuk tujuan pemulihan kerugian keuangan negara. Sedangkan tujuan tersebut hanya dapat dicapai dengan perubahan paradigma baru yaitu keadilan korektif-rehabilitatif dan restoratif. Kekeliruan kedua, selama ini pendekatan hukum dalam proses hukum pengembalian aset tindak pidana selalu digunakan pendekatan hukum normatif yang berlandaskan positivisme hukum. Bila dirinci lebih jauh, setidaknya, 
Available online at: http://ejournal.unpas.ac.id/index.php/litigasi

Litigasi, Vol. 16(2), 2015, 2975-3010

DOI: http://dx.doi.org/10.23969/litigasi.v16i2.44

terdapat 4 (empat) hambatan dan kendala pengembalian aset tindak pidana korupsi dari pelaku dan ahli warisnya dalam sistem hukum Indonesia yakni belum efektifnya gugatan perdata sebagai sarana untuk mengembalikan aset hasil kejahatan korupsi, faktor kelembagaan penegak hukum, belum efektifnya Ratifikasi UNCAC 2003 dilaksanakan dalam hukum Indonesia, serta kelemahan di ranah regulasi tindak pidana korupsi.

\section{B. SARAN}

1. Konsep hukum mendatang dalam pengembalian aset tindak pidana korupsi pelaku dan ahli warisnya dalam mewujudkan negara hukum kesejahteraan, setidaknya ditempuh dalam beberapa langkah hukum progresif, yakni perbaikan regulasi peraturan perundang-undangan terkait tindak pidana korupsi, Penerapan Non-Conviction Based (NCB) Asset Forfeiture, Pengembangan StAR (Stolen Asset Recovery), Optimalisasi Bantuan Hukum Timbal Balik atau Mutual Legal Assistance, Perluasan kewenangan Komisi Pemberantasan Korupsi dalam Pengembalian Aset hasil tindak pidana korupsi, Penguatan koordinasi antar lembaga penegak hukum, serta menyegerakan menyelesaikan Undang-Undang Pengembalian Aset.

Copyright @ $\odot$ 2015, LITIGASI, p-ISSN: 0853-7100; e-ISSN: 2442-2274 
Available online at: http://ejournal.unpas.ac.id/index.php/litigasi

Litigasi, Vol. 16(2), 2015, 2975-3010

DOI: http://dx.doi.org/10.23969/litigasi.v16i2.44

\section{DAFTAR PUSTAKA}

Baharruddin Lopa, 2002, Kejahatan Korupsi dan Penegakan Hukum, cet 2, Jakarta, Penerbit Buku Kompas.

Badan Pembinaan Hukum Nasional Departemen Hukum dan Hak Asasi Manusia RI, 2009, Laporan Lokakarya tentang Pengambilan Aset Negara Hasil Tindak Pidana Korupsi, (Jakarta, Badan Pembinaan Hukum Nasional, 2009).

Eddy O.S Hiariej, Pembuktian Terbalik dalam Pengembalian Aset Kejahatan Korupsi, Pidato Pengukuhan Jabatan Guru Besar pada Fakultas Hukum Universitas Gadjah Mada Diucapkan di depan Rapat Terbuka Majelis Guru Besar Universitas Gadjah Mada pada tanggal 30 Januari 2012 di Yogyakarta.

Purwaning M. Yanuar, 2007, Pengembalian Aset Hasil Korupsi: Berdasarkan Konvensi PBB Anti Korupsi 2003 Dalam Sistem Hukum Indonesia, Bandung, PT Alumni.

Pusat Kajian Antikorupsi Fakultas Hukum UGM bekerjasama dengan Kemitraan melakukan kajian terhadap Pengembalian Aset Kejahatan. Hasil kajian tersebut dibukukan dengan judul "Pengembalian Aset Kejahatan" tahun 2008. Para peneliti juga adalah penulis buku tersebut: Agustinus Pohan, Amien Sunaryadi, Denny Indrayana, Eddy O.S Hiariej, Saldi Isra, Sigit Riyanto, Teten Masduki, Yenti Garnasih dan Zainal Arifin Mochtar.

Suradji Buguati Sutriya, ed., 2008, Pengkajian tentang Kriminalisasi, pengembalian aset, kerjasama internasional dalam konvensi PBB, Jakarta, Badan Pembinaan Hukum Nasional Departemen Hukum dan HAM.

\section{JURNAL}

Eddy O.S Hiariej, 2013, Pengembalian Aset Kejahatan, Jurnal Opinio Juris, Vol. 13, Mei-Agustus 2013.

\section{DISERTASI}

Elwi Danil, 2001, Fungsionalisasi Hukum Pidana Dalam Penanggulangan Tindak Pidana Korupsi; Studi Tentang Urgensi Pembaharuan Hukum Pidana Terhadap Tindak Pidana Korupsi di Indonesia, Disertasi Pada Program Pascasarjana Fakultas Hukum Universitas Indonesia.

Copyright @ 2015, LITIGASI, p-ISSN: 0853-7100; e-ISSN: 2442-2274 


\section{MAKALAH}

Romli Atmasasmita, 2014, Kebijakan Pengembalian Aset Pasca Ratifikasi Konvensi PBB Anti Korupsi-2003 Dalam Sistem Hukum Pidana Indonesia. Makalah pada workshop pemulihan aset tindak pidana, diselenggarakan oleh Mahupiki di Jakarta, 25-29 Agustus 2014.

Saldi Isra, Asset Recovery Tindak Pidana Korupsi Melalui Kerjasama Internasional, Makalah disampaikan dalam Lokakarya tentang Kerjasama Internasional dalam Pemberantasan Korupsi, diselenggarakan atas kerjasama Fakultas Hukum Universias Diponegoro dan Kanwil Depkumham Prov. Jawa Tengah, tanggal 22 Mei 2008, di Semarang. Didownload dari www.saldiisra.com

\section{WEBSITE}

S. Eka Iskandar, Prinsip Pengembalian Aset Hasil Korupsi, dimuat dalam https://gagasanhukum.wordpress.com/2008/09/01/prinsip-pengembalianaset-hasil-korupsi-bagian-ii/. Diakses tanggal 2 Oktober 2014. 